Review Article

\title{
Organic Compounds: Contents and Their Role in Improving Seed Germination and Protocorm Development in Orchids
}

\author{
Edy Setiti Wida Utami and Sucipto Hariyanto (iD \\ Department of Biology, Faculty of Science and Technology, Universitas Airlangga, Surabaya 60115, Indonesia \\ Correspondence should be addressed to Sucipto Hariyanto; sucipto-h@fst.unair.ac.id
}

Received 26 January 2020; Revised 9 May 2020; Accepted 23 May 2020; Published 11 June 2020

Academic Editor: Isabel Marques

Copyright (c) 2020 Edy Setiti Wida Utami and Sucipto Hariyanto. This is an open access article distributed under the Creative Commons Attribution License, which permits unrestricted use, distribution, and reproduction in any medium, provided the original work is properly cited.

In nature, orchid seed germination is obligatory following infection by mycorrhizal fungi, which supplies the developing embryo with water, carbohydrates, vitamins, and minerals, causing the seeds to germinate relatively slowly and at a low germination rate. The nonsymbiotic germination of orchid seeds found in 1922 is applicable to in vitro propagation. The success of seed germination in vitro is influenced by supplementation with organic compounds. Here, we review the scientific literature in terms of the contents and role of organic supplements in promoting seed germination, protocorm development, and seedling growth in orchids. We systematically collected information from scientific literature databases including Scopus, Google Scholar, and ProQuest, as well as published books and conference proceedings. Various organic compounds, i.e., coconut water (CW), peptone $(\mathrm{P})$, banana homogenate $(\mathrm{BH})$, potato homogenate $(\mathrm{PH})$, chitosan $(\mathrm{CHT})$, tomato juice $(\mathrm{TJ})$, and yeast extract $(\mathrm{YE})$, can promote seed germination and growth and development of various orchids. They also stimulate seedling development, formation of protocorm-like bodies (PLBs), plantlet growth, and multiple shoot formation. The addition of organic compounds to culture media, individually or in combination, accelerates seed germination and seedling development. Different types and concentrations of organic nutrients are needed for the success of in vitro cultures, depending on the species and genotype.

\section{Introduction}

Orchids, member of the Orchidaceae, are one of the largest and most diverse families of flowering plants, consisting of 763 genera and more than 28,000 accepted species [1]. Orchids are found in various habitats, primarily (70\%) attached to tree trunks in forests as epiphytes, growing in the shade and comprising almost two-thirds of the world's epiphytic flora; the remaining $25 \%$ are terrestrial, while $5 \%$ are found on various support systems [2,3].

Orchid seeds have limited food storage tissue, which is needed for germination and protocorms development, making seed germination in natural conditions relatively low $(<5 \%)[4,5]$. Under natural conditions, mature seeds depend on compatible mycorrhizal fungi for germination and early development $[6,7]$. Therefore, in vitro orchid seed germination is a crucial aspect in propagation and conservation programs. Seeds cultured in vitro can develop into complete seedlings without the aid of fungi, which is a suitable approach for commercial orchid production [8-12].

Initially, in vitro seed germination used mycorrhizal fungi isolated from various natural environments for stimulation and was known as "symbiotic seed germination." The addition of organic nutrients to in vitro culture was meant to stimulate seed germination. In 1922, Knudson [13] successfully developed a method to stimulate protocorm production in orchids by culturing the seeds in vitro and sprinkling them on sterile nutrient media plus sucrose. This technique was known as "asymbiotic seed germination" because it did not involve mycorrhizal fungi. Both approaches were effective.

\section{The Orchid Seed}

Orchid seeds are the smallest of those produced by flowering plants and are therefore called "dust seeds" [14]. However, 
despite their microscopic structure, they exhibit a wide variety in shape, size, color, weight, testa (cell number, size, ornamentation), and embryo characteristics.

According to Molvray and Kores [15], orchid seeds can be crescent, broadly ellipsoid, filamentous, spindle-shaped, fusiform, oblong, irregular, or clavate. Verma et al. [16] established that ovoid, filiform, and spatulate-shaped seeds are present in Androcorys monophylla, Goodyera biflora, and Platanthera clavigera, respectively.

Seed color also varies, including orange yellow in Dendrobium formosum and Dendrobium densiflorum, brownish yellow in Dendrobium hookerianum, yellow in Cymbidium bicolor, white in Eria dalzellii, pale yellow in Liparis elliptica and Pholidota pallida, golden yellow in Bulbophyllum mysorense, and light yellow in Coelogyne breviscapa $[16,17]$. Molvray and Kores [15] showed that seed size varied from 150 to $6,000 \mu \mathrm{m}$ and weight ranged from 0.31 to $24 \mu \mathrm{g}$.

The cellular organization of seed is simple and consists of an undifferentiated mass of embryonal cells and a rudimentary endosperm, covered with a transparent testa [18]. According to Arditti and Ghani [14], orchid embryos are relatively small and simple, generally oval or spherical in shape, and sometimes consist of only a few cells, mostly without an endosperm.

\section{The Role of Organic Nutrient Supplements}

The development and regeneration of in vitro cultured plant tissues can be improved by adding a variety of organic nutrients [19-21]. These may include coconut water (CW), peptone $(\mathrm{P})$, potato homogenate $(\mathrm{PH})$, banana homogenate $(\mathrm{BH})$, chitosan $(\mathrm{CHT})$, tomato juice $(\mathrm{TJ})$, and yeast extract (YE). Organic nutrients are a source of vitamins, amino acids, fatty acids, carbohydrates, peptides, and growth factors, which all facilitate growth [22]. Few organic nutrients have been studied for their contents and role in improving seed germination and development of the protocorm in orchids using in vitro models (Table 1, Figure 1). Some of these studies are discussed in the following sections.

\section{Coconut Water}

$\mathrm{CW}$ is a colorless liquid endosperm obtained from Cocos nucifera. It is often added to culture media containing auxin for the rapid induction of propagation and cell growth. The use of CW in tissue culture was first attempted by Van Overbeek et al. $[64,65]$, who reported that adding it to the culture medium was essential for the development of young Datura stramonium embryos.

CW contains soluble sugars as a natural source of carbon, as well as amino acids and vitamins, such as thiamin, pyridoxine, ascorbic acid, and minerals [66, 67]. It also consists of various organic ions such as phosphorus, magnesium, potassium, calcium, iron, and manganese $[68,69]$, all of which facilitate germination [70]. Furthermore, CW contains indoleacetic acid (IAA), abscisic acid (ABA), gibberellic acid (GA), and zeatin [71], which are generally used as growth supplements in plant tissue culture.
Orchid seed germination is usually increased by adding CW to the medium (Table 1). For instance, Thomas and Michael [23] reported 93\% germination of Rhynchostylis retusa seeds after the addition of $150 \mathrm{~mL} \cdot \mathrm{L}^{-1}$ of CW to a halfstrength Murashige and Skoog medium ( $1 \frac{2}{2}$ MS; Murashige and Skoog [72]). Similar conclusions were reached by Piri et al. [24], who stated that the addition of CW $150 \mathrm{~mL} \cdot \mathrm{L}^{-1}$ to Mitra medium (M; Mitra et al. [73]) was most suitable for seed germination of Acampe papillosa.

According to Huh et al. [25], MS medium supplemented with CW enhances seed germination and protocorm formation of Cypripedium macranthos. In a study of different organic supplements, including CW, birch sap (BS), maple sap (MPS), BH, and $\mathrm{P}$, at various concentrations, the use of $100 \mathrm{~mL} \cdot \mathrm{L}^{-1} \mathrm{CW}$ resulted in the highest germination rate (70.8\%) and protocorm formation rate (74.2\%). Zeng et al. [26] also established that $1 / 2$ MS medium containing $0.5 \mathrm{mg} \cdot \mathrm{L}^{-1} \alpha$-naphthaleneacetic acid (NAA) and $1.0 \mathrm{~g} \cdot \mathrm{L}^{-1}$ activated charcoal (AC) supplemented with CW, enhanced seed germination and seedling formation of Paphiopedilum wardii. Among the different organic supplements, including $\mathrm{CW}, \mathrm{PH}, \mathrm{BH}$, tryptone $(\mathrm{T})$, and $\mathrm{P}$ with various concentrations, $100 \mathrm{~mL} \cdot \mathrm{L}^{-1} \mathrm{CW}$ increased seed germination $(65.33 \%)$ and had the highest seedling formation $(35.67 \%)$ compared to other treatments, while $\mathrm{Wu}$ et al. [27] concluded that $1 / 4 \mathrm{MS}$ medium containing $0.5 \mathrm{mg} \cdot \mathrm{L}^{-1} \mathrm{NAA}$ and $1 \mathrm{~g} \cdot \mathrm{L}^{-1}$ AC, supplemented with $200 \mathrm{~mL} \cdot \mathrm{L}^{-1} \mathrm{CW}$ and $1 \mathrm{~g} \cdot \mathrm{L}^{-1}$ $\mathrm{P}$, after 75 days in culture, was suitable for seed germination and protocorm development of Renanthera imschootiana.

CW not only affects germination and protocorm development, but also plays an important role in the formation of protocorm-like bodies (PLBs), plantlet growth, and multiple shoot induction. According to Baque et al. [28], the Hyponex medium, Kano [74], supplemented with CW effectively enhanced plantlet growth of ornamental orchid Calanthe hybrids. Of the various CW concentrations tested $\left(0,10,30,50\right.$, and $\left.100 \mathrm{~mL} \cdot \mathrm{L}^{-1}\right)$, a concentration of $50 \mathrm{~mL} \cdot \mathrm{L}^{-1}$ significantly increased plantlet dry weight. Maharjan et al. [29] assayed the effect of different concentrations of CW $\left(0,50\right.$, and $\left.100 \mathrm{~mL} \cdot \mathrm{L}^{-1}\right)$ on shoot formation of medicinal orchid Vanda pumila protocorms and found that the number and length of shoot increased when cultured on $1 / 2$ MS medium supplemented with CW. Similar conclusions were made by Punjansing et al. [30] who determined that the addition of CW $\left(50 \mathrm{~mL} \cdot \mathrm{L}^{-1}\right)$ to $1 / 2 \mathrm{MS}$ medium containing $50 \mathrm{~g} \cdot \mathrm{L}^{-1} \mathrm{PH}$ was the best for promoting shoot multiplication of Phaius tankervilleae var. alba. This result was supported earlier by Jainol and Jualang [31] who observed the effects of different organic supplements (CW, TJ, BH, P, and YE) at various concentrations on multiple shoot formation in Dimorphorchis lowii and found that CW at $150 \mathrm{~mL} \cdot \mathrm{L}^{-1}$ resulted in the highest number of shoots. Kaur et al. [32] investigated the effects of the addition of various organic supplements $(\mathrm{BH}, \mathrm{CW}$, and control without organic additives) at various concentrations on the in vitro multiplication of protocorms in a medicinal orchid (Dendrobium nobile). In their study, $\mathrm{M}$ medium supplemented with $200 \mathrm{~mL} \cdot \mathrm{L}^{-1} \mathrm{CW}$ was the most suitable for the enhancement of protocorms multiplication. 
TABLE 1: Effects of organic supplements on orchid seed germination and protocorm development.

\begin{tabular}{|c|c|c|c|c|}
\hline Media & Species & Organic supplements (OS) & Key results obtained & References \\
\hline $1 / 2$ MS & Rhynchostylis retusa & CW: $0,50,100,150,200 \mathrm{~mL} \cdot \mathrm{L}^{-1}$ & $\begin{array}{l}\text { The fastest germination ( } 14 \text { days) and highest } \\
\text { germination rate ( } 93 \%) \text { were found in } 1 / 2 \mathrm{MS} \\
\text { medium supplemented with CW }\left(150 \mathrm{~mL} \cdot \mathrm{L}^{-1}\right) \text {. } \\
\text { Of the forty-five plantlets transplanted to soil, } \\
\text { forty survived. }\end{array}$ & {$[23]$} \\
\hline M & Acampe papillosa & $\begin{array}{l}\text { CW: } 0,150 \mathrm{~mL} \cdot \mathrm{L}^{-1} \\
\text { YE: } 0,2 \mathrm{~g} \cdot \mathrm{L}^{-1}\end{array}$ & $\begin{array}{l}\text { Addition of } \mathrm{CW} \text { at } 150 \mathrm{~mL} \cdot \mathrm{L}^{-1} \text { to } \mathrm{M} \text { medium } \\
\text { accelerated germination and seedling formation, } \\
\text { with a germination rate of } 70.75 \% \text {. Complete } \\
\text { seedlings were then transferred to clay pots with } \\
\text { a media mixture of brick pieces, sphagnum } \\
\text { moss, pine bark, and charcoal pieces }(1: 1: 1: 1) \text {, } \\
\text { where } 70 \% \text { of seedlings survived. }\end{array}$ & {$[24]$} \\
\hline
\end{tabular}

\begin{tabular}{|c|c|c|c|c|}
\hline MS & Cypripedium macranthos & $\begin{array}{l}\text { CW: } 0,50,100,200 \mathrm{~mL} \cdot \mathrm{L}^{-1} \\
\text { BS: } 0,50,100,200 \mathrm{~mL} \cdot \mathrm{L}^{-1} \\
\text { MPS: } 0,50,100,200 \mathrm{~mL} \cdot \mathrm{L}^{-1} \\
\text { BH: } 0,15,30,60 \mathrm{~g} \cdot \mathrm{L}^{-1} \\
\text { P: } 0,1,2,4 \mathrm{~g} \cdot \mathrm{L}^{-1}\end{array}$ & $\begin{array}{l}\text { An optimum seed germination rate of } 70.8 \% \text { and } \\
\text { protocorm formation rate of } 74.2 \% \text { were } \\
\text { obtained on MS medium with } 100 \mathrm{~mL} \cdot \mathrm{L}^{-1} \mathrm{CW} \text {. }\end{array}$ & {$[25]$} \\
\hline $1 / 2 \mathrm{MS}$ & Paphiopedilum wardii & $\begin{array}{l}\text { CW: } 0,50,75,100,150 \mathrm{~mL} \cdot \mathrm{L}^{-1} \\
\text { PH: } 25,50,75,100 \mathrm{~g} \cdot \mathrm{L}^{-1} \\
\text { BH: } 25,50,75,100 \mathrm{~g} \cdot \mathrm{L}^{-1} \\
\text { T: } 0.5,1,1.5 \mathrm{~g} \cdot \mathrm{L}^{-1}\end{array}$ & $\begin{array}{l}\text { The fastest germination (65 days) and an } \\
\text { optimum seed germination rate }(65.33 \%) \text { and } \\
\text { seedling formation rate }(35.67 \%) \text { were achieved } \\
\text { on } 1 / 2 \text { MS medium containing NAA } 0.5 \mathrm{mg} \cdot \mathrm{L}^{-1} \\
\text { and AC } 1 \mathrm{~g} \cdot \mathrm{L}^{-1} \text { supplemented with } 100 \mathrm{~mL} \cdot \mathrm{L}^{-1} \\
\mathrm{CW} \text {. Zeng et al. [26] also reported that plantlets, } \\
5 \mathrm{~cm} \text { in height, were then transplanted into pots } \\
\text { with a media mixture }(1: 2: 1 ; \mathrm{v} / \mathrm{v} / \mathrm{v}) \text { of shattered } \\
\text { fir bark, stone for orchid, and sieved peat. After } \\
180 \text { days in a greenhouse, } 92.33 \% \text { of plantlets } \\
\text { survived. }\end{array}$ & {$[26]$} \\
\hline $1 / 4 \mathrm{MS}$ & Renanthera imschootiana & $\begin{array}{c}\text { CW: } 0,100,150,200,250 \mathrm{~mL} \cdot \mathrm{L}^{-1} \\
\text { T: } 0,0.5,1,1.5 \mathrm{~g} \cdot \mathrm{L}^{-1} \\
\text { P: } 0,0.5,1,1.5 \mathrm{~g} \cdot \mathrm{L}^{-1} \\
\text { PH: } 0,0.5,1.5,2.0 \mathrm{~g} \cdot \mathrm{L}^{-1} \\
\text { BH: } 0,0.5,1.5,2.0 \mathrm{~g} \cdot \mathrm{L}^{-1} \\
\text { CW: } 200 \mathrm{~mL} / \mathrm{L}+\mathrm{P} 0.5 \mathrm{~g} \cdot \mathrm{L}^{-1} \\
\text { CW: } 200 \mathrm{~mL} / \mathrm{L}+\mathrm{P} 1 \mathrm{~g} \cdot \mathrm{L}^{-1} \\
\text { CW: } 200 \mathrm{~mL} / \mathrm{L}+\mathrm{P} 1.5 \mathrm{~g} \cdot \mathrm{L}^{-1}\end{array}$ & $\begin{array}{l}1 / 4 \text { MS medium containing } 0.5 \mathrm{mg} \cdot \mathrm{L}^{-1} \mathrm{NAA} \text {, } \\
1 \mathrm{~g} \cdot \mathrm{L}^{-1} \mathrm{AC} \text {, supplemented with } 200 \mathrm{~mL} \cdot \mathrm{L}^{-1} \mathrm{CW} \text {, } \\
\text { and } 1 \mathrm{~g} \cdot \mathrm{L}^{-1} \mathrm{P} \text { was most suitable for seed } \\
\text { germination }(93.10 \%) \text { and protocorm } \\
\text { development }(41.10 \%) \text { at stage } 5 \text { (seedling). } \\
\text { Survival of Renanthera imschootiana plantlets } \\
\text { (95\%) was found } 60 \text { days after transplanting into } \\
\text { pots with sphagnum moss in the greenhouse. }\end{array}$ & {$[27]$} \\
\hline Hyponex & Calanthe hybrids & $\mathrm{CW}: 0,10,30,50,100 \mathrm{~mL} \cdot \mathrm{L}^{-1}$ & $\begin{array}{l}\text { A CW concentration of } 50 \mathrm{~mL} \cdot \mathrm{L}^{-1} \text { significantly } \\
\text { increased plantlet dry weight and fresh weight. }\end{array}$ & {$[28]$} \\
\hline $1 / 2 \mathrm{MS}$ & Vanda pumila & $\begin{array}{l}\text { CW: } 0,50,100 \mathrm{~mL} \cdot \mathrm{L}^{-1} \\
\text { Kin: } 0,1,2 \mathrm{mg} \cdot \mathrm{L}^{-1}\end{array}$ & $\begin{array}{l}\text { The highest number of shoots ( } 9.5 \text { shoots/ } \\
\text { culture) was obtained when the protocorm was } \\
\text { cultured on } 1 / 2 \mathrm{MS} \text { medium containing } 1 \mathrm{mg} \cdot \mathrm{L}^{-1} \\
\text { Kin added to } 100 \mathrm{~mL} \cdot \mathrm{L}^{-1} \mathrm{CW} \text {. The longest } \\
\text { shoots }(0.7 \mathrm{~cm} / \text { culture) were obtained when } \\
\text { protocorm was cultured on } 1 / 2 \mathrm{MS} \text { medium } \\
\text { containing } 2 \mathrm{mg} \cdot \mathrm{L}^{-1} \text { BAP added to } 100 \mathrm{~mL} \cdot \mathrm{L}^{-1} \\
\text { CW. }\end{array}$ & [29] \\
\hline $1 / 2 \mathrm{MS}$ & $\begin{array}{c}\text { Phaius tankervilleae var. } \\
\text { alba }\end{array}$ & $\begin{array}{c}\text { CW: } 0,50,100,150,200 \mathrm{~mL} \cdot \mathrm{L}^{-1} \\
\text { PH: } 0,25,50 \mathrm{~g} \cdot \mathrm{L}^{-1}\end{array}$ & $\begin{array}{l}\text { The highest number of shoots ( } 3.0 \text { shoots/ } \\
\text { explant) was found when protocorm was } \\
\text { cultured on } 1 / 2 \text { MS medium containing } 50 \mathrm{~g} \cdot \mathrm{L}^{-1} \\
\text { PH and supplemented with } 50 \mathrm{~mL} \cdot \mathrm{L}^{-1} \mathrm{CW} \text {. }\end{array}$ & {$[30]$} \\
\hline $\mathrm{KC}$ & Dimorphorchis lowii & $\begin{array}{l}\text { CW: } 100,150,200 \mathrm{~mL} \cdot \mathrm{L}^{-1} \\
\text { TJ: } 100,150,200 \mathrm{~mL} \cdot \mathrm{L}^{-1} \\
\text { BH: } 25,75,125 \mathrm{~mL} \cdot \mathrm{L}^{-1} \\
\text { P: } 1,2,5 \mathrm{~g} \cdot \mathrm{L}^{-1} \\
\text { YE: } 0,2 \mathrm{~g} \cdot \mathrm{L}^{-1}\end{array}$ & $\begin{array}{l}\text { A CW concentration of } 150 \mathrm{~mL} \cdot \mathrm{L}^{-1} \text { yielded the } \\
\text { highest percentage of explant forming shoots } \\
(100 \%) \text {, number of shoots per explant }(13.83) \text {, } \\
\text { and shoot length }(38.86 \mathrm{~mm}) \text {. }\end{array}$ & {$[31]$} \\
\hline
\end{tabular}


TABle 1: Continued.

\begin{tabular}{|c|c|c|c|c|}
\hline Media & Species & Organic supplements (OS) & Key results obtained & References \\
\hline M & Dendrobium nobile & $\begin{array}{l}\text { BH: } 0,10,20,30 \mathrm{~g} \cdot \mathrm{L}^{-1} \\
\mathrm{CW}: 100,200,300 \mathrm{~mL} \cdot \mathrm{L}^{-1}\end{array}$ & $\begin{array}{l}\text { A CW concentration of } 200 \mathrm{~mL} \cdot \mathrm{L}^{-1} \text { in } \mathrm{M} \\
\text { medium resulted in the highest percentage of } \\
\text { regeneration }(80.25 \%) \text { and the highest number } \\
\text { of PLBs/protocorm }(10) \text {. }\end{array}$ & {$[32]$} \\
\hline VW & Dendrobium lasianthera & $\mathrm{P}: 0,1,2,3 \mathrm{~g} \cdot \mathrm{L}^{-1}$ & $\begin{array}{l}\text { After } 12 \text { weeks of culture, a seed germination } \\
\text { rate of } 100 \% \text { was observed in all treatments. } \\
\text { Plantlets, } 2-3 \mathrm{~cm} \text { in height, were transplanted } \\
\text { into plastic pots with a media mixture of coconut } \\
\text { fiber and sphagnum moss }(3: 1 ; \mathrm{v} / \mathrm{v}) \text { and } \\
\text { acclimated in greenhouse. More than } 90 \% \text { of } \\
\text { plantlets survived. }\end{array}$ & {$[33]$} \\
\hline $\begin{array}{l}\mathrm{PM}, \mathrm{MS}, \\
\mathrm{M}\end{array}$ & $\begin{array}{c}\text { Epidendrum ibaguense } \\
\text { Kunth }\end{array}$ & $\mathrm{P}: 0,2 \mathrm{~g} \cdot \mathrm{L}^{-1}$ & $\begin{array}{c}\text { Supplementation with } 2 \mathrm{~g} \cdot \mathrm{L}^{-1} \mathrm{P} \text { in } \mathrm{M} \text { and } \mathrm{PM} \\
\text { media increased germination and improved } \\
\text { protocorm growth }(90 \%) \text { over the control } \\
\text { (without } \mathrm{P} \text { ). The healthy in vitro plantlets with } 2 \\
\text { to } 3 \text { leaves were individually grown in pots with } \\
\text { a mixture of peat moss, brick pieces, and } \\
\text { charcoal pieces }(0.25: 1: 1) \text {, and } 90 \% \text { plantlets } \\
\text { survived. }\end{array}$ & {$[34]$} \\
\hline PM, MS & Spathoglottis plicata Blume & P: $0,2 \mathrm{~g} \cdot \mathrm{L}^{-1}$ & $\begin{array}{l}\text { The highest percentage of seed germination } \\
(95 \%) \text { was obtained on PM medium } \\
\text { supplemented with } 2 \mathrm{~g} \cdot \mathrm{L}^{-1} \mathrm{P} \text {. The well-rooted } \\
\text { plantlets were transferred to pots containing a } \\
\text { mixture composed of saw dust, coconut coir, } \\
\text { humus, and coal pieces at }(1: 1: 1: 2 ; \mathrm{w} / \mathrm{w} / \mathrm{w} / \mathrm{w}) \\
\text { and had an } 80 \% \text { survival rate in an outside } \\
\text { environment. }\end{array}$ & {$[35]$} \\
\hline $\mathrm{KC}$ & Dendrobium parishii & P: $0,2 \mathrm{~g} \cdot \mathrm{L}^{-1}$ & $\begin{array}{l}\text { The highest percentage of seed germination } \\
(100 \%) \text { was obtained when } \mathrm{KC} \text { medium was } \\
\text { supplemented with } 2 \mathrm{~g} \cdot \mathrm{L}^{-1} \mathrm{P}\end{array}$ & {$[36]$} \\
\hline $\mathrm{KC}, \mathrm{MS}$ & $\begin{array}{c}\text { Aerides ringens (Lindl.) } \\
\text { Fischer }\end{array}$ & $\mathrm{P}: 0,0.25,0.5,0.75 \mathrm{~g} \cdot \mathrm{L}^{-1}$ & $\begin{array}{l}\text { The highest seed germination rate }(89.28 \%) \text { was } \\
\text { recorded in KC medium containing } 8.9 \mu \mathrm{M} \text { BAP } \\
\text { supplemented with } 0.5 \mathrm{~g} \cdot \mathrm{L}^{-1} \mathrm{P} \text {. Seeds cultivated } \\
\text { on this medium also had the fastest growth } \\
(55-65 \text { days }) \text { and the largest protocorm size } \\
(1.89 \mathrm{~mm}) \text {. Plantlets regenerated via in vitro seed } \\
\text { germination processes were transferred into pots } \\
\text { with a mixture of charcoal, broken brick pieces, } \\
\text { and/or tree fern roots and had an } 80 \% \text { survival } \\
\text { rate. }\end{array}$ & {$[37]$} \\
\hline $1 / 2 \mathrm{MS}$ & Taprobanea spathulata & $\begin{array}{l}\text { P: } 1.25,2.5,5 \mathrm{~g} \cdot \mathrm{L}^{-1} \\
\text { TJ: } 5,10,15 \%(\mathrm{w} / \mathrm{v}) \\
\text { CW: } 5,10,15 \mathrm{~mL} \cdot \mathrm{L}^{-1}\end{array}$ & $\begin{array}{c}\text { A P concentration of } 5 \mathrm{~g} \cdot \mathrm{L}^{-1} \text { resulted in the most } \\
\text { significant induction of multiple protocorm } \\
(14.64) .\end{array}$ & {$[38]$} \\
\hline BM-1 & Paphiopedilum venustum & $\begin{array}{l}\text { BH: } 0,10,20,30 \mathrm{~g} \cdot \mathrm{L}^{-1} \\
\text { P: } 0,1,2 \mathrm{~g} \cdot \mathrm{L}^{-1}\end{array}$ & $\begin{array}{l}\text { A P concentration of } 1 \mathrm{~g} \cdot \mathrm{L}^{-1} \text { facilitated the } \\
\text { highest regeneration of adventitious shoots per } \\
\text { explant (3.05) and the highest total number of } \\
\text { plantlets per shoot }(4.05) \text {. }\end{array}$ & {$[39]$} \\
\hline Hyponex & Vanda roxburgii & PH: $0,2.5,5,10,20 \%(\mathrm{w} / \mathrm{v})$ & $\begin{array}{c}\text { A PH concentration of } 20 \% \text { significantly } \\
\text { increased germination from } 17.2 \% \text { (control) to } \\
78.24 \% \text {. }\end{array}$ & {$[40]$} \\
\hline VW & Dimorphorchis lowii & $\begin{array}{l}\text { CW: } 0,10 \%(\mathrm{v} / \mathrm{v}) \\
\text { PH: } 0,10 \%(\mathrm{w} / \mathrm{v}) \\
\text { TJ: } 0,10 \%(\mathrm{w} / \mathrm{v})\end{array}$ & $\begin{array}{c}\text { Seeds from } 150 \text {-day-old capsules, grown on VW } \\
\text { medium supplemented with } 10 \% \mathrm{PH} \text {, showed } \\
\text { the highest germination rate }(98.02 \%) \text {, followed } \\
\text { by } 10 \% \mathrm{CW}(97.23 \%), 10 \% \mathrm{TJ}(93.71 \%) \text {, and the } \\
\text { control }(91.79 \%) .\end{array}$ & {$[41]$} \\
\hline $1 / 2 \mathrm{MS}$ & Dendrobium tosaense & $\begin{array}{l}\text { BH: } 0,8 \%(\mathrm{w} / \mathrm{v}) \\
\text { PH: } 0,8 \%(\mathrm{w} / \mathrm{v}) \\
\text { CW: } 0,8 \%(\mathrm{v} / \mathrm{v})\end{array}$ & $\begin{array}{l}\text { At a PH concentration of } 8 \% \text {, the highest } \\
\text { seedling fresh weight }(0.39 \mathrm{~g}) \text { and longest root } \\
\text { length }(7.7 \mathrm{~cm}) \text { were obtained. }\end{array}$ & {$[42]$} \\
\hline
\end{tabular}


TABle 1: Continued.

\begin{tabular}{|c|c|c|c|c|}
\hline Media & Species & Organic supplements (OS) & Key results obtained & References \\
\hline $1 / 2 \mathrm{MS}$ & Dendrobium officinale & PH: $0,25,50,100 \%(\mathrm{w} / \mathrm{v})$ & $\begin{array}{l}\text { The optimal shoot multiplication and shoot } \\
\text { growth medium for Dendrobium officinale was } \\
1 / 2 \mathrm{MS} \text { containing } 0.1 \mathrm{mg} \cdot \mathrm{L}^{-1} \mathrm{NAA} \text { and } 2 \mathrm{mg} \cdot \mathrm{L}^{-1} \\
\text { BA and supplemented with } 100 \% \mathrm{PH} \text {. This } \\
\text { medium yielded a multiplication rate of } 6.2 \text { and } \\
\text { a shoot length of } 2.5 \mathrm{~cm} \text {. }\end{array}$ & {$[43]$} \\
\hline VW & Bulbophyllum nipondhii & PH: $0,25,50,75 \mathrm{~g} \cdot \mathrm{L}^{-1}$ & $\begin{array}{l}\text { VW medium containing } 100 \mathrm{~mL} \cdot \mathrm{L}^{-1} \mathrm{CW} \text { and } \\
\text { supplemented with } 75 \mathrm{~g} \cdot \mathrm{L}^{-1} \mathrm{PH} \text {, showed the } \\
\text { highest number of new pseudobulbs/explant } \\
\text { (3.5), number of roots/explant (8.1), mean root } \\
\text { length }(13.6 \mathrm{~mm}) \text {, and mean leaf length } \\
(19.2 \mathrm{~mm}) \text {. }\end{array}$ & {$[44]$} \\
\hline MM & Chloraea gavilu & $\begin{array}{l}\text { BH: } 0,100 \mathrm{~g} \cdot \mathrm{L}^{-1} \\
\text { TJ: } 0,100 \%(\mathrm{w} / \mathrm{v})\end{array}$ & $\begin{array}{l}\text { BH successfully improved germination, } \\
\text { reaching a rate of over } 90 \% \text {. }\end{array}$ & {$[45]$} \\
\hline $1 / 2 \mathrm{MS}$ & Dendrobium sp. & $\mathrm{BH}: 0,2.5,5,10,20 \%(\mathrm{w} / \mathrm{v})$ & $\begin{array}{c}\text { At a } \mathrm{BH} \text { concentration of } 10 \%, \mathrm{PLB} \text { regeneration } \\
\text { was highest with } 554 \mathrm{PLBs} / \text { culture. }\end{array}$ & {$[46]$} \\
\hline $\mathrm{HO}_{26}$ & Paphiopedilum hangianum & BH: $0,50,100 \mathrm{~g} \cdot \mathrm{L}^{-1}$ & $\begin{array}{c}\mathrm{HO}_{26} \text { medium containing } 1 \mathrm{~g} \cdot \mathrm{L}^{-1} \mathrm{P} \text { and } 1 \mathrm{mg} \cdot \mathrm{L}^{-1} \\
\mathrm{NAA} \text { and supplemented with } 100 \mathrm{~g} \cdot \mathrm{L}^{-1} \mathrm{BH} \text {, was } \\
\text { suitable for plantlet formation }(95.33 \%) \text {. Plants } \\
\text { regenerated by in vitro germination processes } \\
\text { were successfully grown in greenhouse } \\
\text { conditions for } 180 \text { days with a survival rate of } \\
88.5 \% \text {. }\end{array}$ & {$[47]$} \\
\hline Harvais & Cypripedium macranthos & $\begin{array}{l}\text { CW: } 0,50,100 \mathrm{~mL} \cdot \mathrm{L}^{-1} \\
\text { PH: } 0,25,50 \mathrm{~g} \cdot \mathrm{L}^{-1} \\
\text { BH: } 0,25,50 \mathrm{~g} \cdot \mathrm{L}^{-1}\end{array}$ & $\begin{array}{l}\text { Among the investigated organic supplements, } \\
\text { the addition of } \mathrm{BH}\left(25 \text { and } 50 \mathrm{~g} \cdot \mathrm{L}^{-1}\right) \text { improved } \\
\text { shoot number, root number, shoot length, and } \\
\text { root length. }\end{array}$ & {$[48]$} \\
\hline KC & Hadrolaelia purpurata & $\begin{array}{l}\text { BH: } 0,90 \mathrm{~g} \cdot \mathrm{L}^{-1} \\
\text { P: } 0,1 \mathrm{~g} \cdot \mathrm{L}^{-1} \\
\text { CW: } 0,150 \mathrm{~mL} \cdot \mathrm{L}^{-1}\end{array}$ & $\begin{array}{c}\text { Highest seedling number }(90.08) \text { and leaf } \\
\text { number (3.19) were obtained in } \mathrm{KC} \text { medium } \\
\text { supplemented with } 90 \mathrm{~g} \cdot \mathrm{L}^{-1} \mathrm{BH} \text {. }\end{array}$ & {$[49]$} \\
\hline VW & Phalaenopsis amboinensis & $\begin{array}{c}\mathrm{CW}: 150 \mathrm{~mL} \cdot \mathrm{L}^{-1} \\
\mathrm{CW}: 150 \mathrm{~mL} \cdot \mathrm{L}^{-1}+\mathrm{BH} 5 \mathrm{~g} \cdot \mathrm{L}^{-1} \\
\mathrm{CW}: 150 \mathrm{~mL} \cdot \mathrm{L}^{-1}+\mathrm{BH} 10 \mathrm{~g} \cdot \mathrm{L}^{-1}\end{array}$ & $\begin{array}{l}\text { Among the surveyed organic supplements, } \\
150 \mathrm{~mL} \cdot \mathrm{L}^{-1} \mathrm{CW} \text { together with } 10 \mathrm{~g} \cdot \mathrm{L}^{-1} \mathrm{BH} \text { in } \\
\mathrm{VW} \text { medium increased plantlets growth to the } \\
\text { maximum height }(62.1 \mathrm{~mm}) \text { and dry weight } \\
(15.5 \mathrm{~g}) . \text { Plants regenerated via asymbiotic seed } \\
\text { germination processes were successfully } \\
\text { acclimatized in greenhouse conditions, and the } \\
\text { survival rate was greater than } 85 \% \text {. }\end{array}$ & {$[50]$} \\
\hline
\end{tabular}

CHT polymers: $\mathrm{P}_{70}, \mathrm{P}_{80}, \mathrm{P}_{90}$ with five concentrations: $0,10,20,40$,

DW Dendrobium bigibbum and
Dendrobium formosum
$80 \mathrm{mg} \cdot \mathrm{L}^{-1}$

CHT oligomers: $\mathrm{O}_{70}, \mathrm{O}_{80}, \mathrm{O}_{90}$ with five concentrations: $0,10,20$, $40,80 \mathrm{mg} \cdot \mathrm{L}^{-1}$

The highest rate of seed germination (91.2\%) was obtained with $\mathrm{CHT}$ type $\mathrm{O}_{80}$ at $10 \mathrm{mg} \cdot \mathrm{L}^{-1}$ using Dendrobium formosum.

The highest fresh weight of PLBs $(0.83 \mathrm{~g})$, VW Dendrobium sp. CHT: $0,5,10,15,20,25 \mathrm{mg} \cdot \mathrm{L}^{-1} \quad \begin{gathered}\text { number of PLBs (12.33), and number of plantlets } \\ (6.66) \text { were obtained using VW medium }\end{gathered}$ supplemented with $15 \mathrm{mg} \cdot \mathrm{L}^{-1} \mathrm{CHT}$.

At a CHT concentration of $15 \mathrm{mg} \cdot \mathrm{L}^{-1}$, the

VW Dendrobium phalaenopsis

Shrimp CHT: 0, 5, 10, 15, 20, $25 \mathrm{mg} \cdot \mathrm{L}^{-1}$

highest PLB growth from meristematic buds was observed, with a fresh weight of $0.15 \mathrm{~g}$.

The use of CHT at $15 \mathrm{mg} \cdot \mathrm{L}^{-1}$ increased the PLB diameter $(69 \mathrm{~mm})$ when compared to the control $(54 \mathrm{~mm})$. Similarly this treatment

$1 / 2$ MS Grammatophyllum speciosum
CHT: 0, 5, 10, 15, 20, 25, 50 $100 \mathrm{mg} \cdot \mathrm{L}^{-1}$ yielded the highest number of new PLBs/explant 
TABLE 1: Continued.

\begin{tabular}{|c|c|c|c|c|}
\hline Media & Species & Organic supplements (OS) & Key results obtained & References \\
\hline VW & Phalaenopsis gigantea & CHT: $0,5,10,15,20,25 \mathrm{mg} \cdot \mathrm{L}^{-1}$ & $\begin{array}{c}\text { After } 20 \text { weeks of cultivation, } 10 \mathrm{mg} \cdot \mathrm{L}^{-1} \mathrm{CHT} \\
\text { resulted in the highest increase in PLB fresh } \\
\text { weight }(3.4 \mathrm{~g}) \text { compared with other treatments: } \\
\text { control }(1.5 \mathrm{~g}), 5 \mathrm{mg} \cdot \mathrm{L}^{-1}(1.2 \mathrm{~g}), 15 \mathrm{mg} \cdot \mathrm{L}^{-1} \\
(0.8 \mathrm{~g}), 20 \mathrm{mg} \cdot \mathrm{L}^{-1}(1.3 \mathrm{~g}) \text {, and } 25 \mathrm{mg} \cdot \mathrm{L}^{-1}(1.2 \mathrm{~g}) \\
\text { respectively. }\end{array}$ & {$[55]$} \\
\hline $\begin{array}{l}\text { Green } \\
\text { house }\end{array}$ & $\begin{array}{l}\text { Grammatophyllum } \\
\text { scriptum }\end{array}$ & CHT: $0,0.5,0.75,1 \mathrm{~g} \cdot \mathrm{L}^{-1}$ & $\begin{array}{c}\text { The effective addition of CHT at concentrations } \\
\text { of } 0.5-0.75 \mathrm{~g} \cdot \mathrm{L}^{-1} \text { resulted in a plant height of } \\
0.8 \mathrm{~cm} \text { and a leaf length of } 0.5 \mathrm{~cm} \text {. }\end{array}$ & {$[56]$} \\
\hline $\begin{array}{l}\text { Green } \\
\text { house }\end{array}$ & Dendrobium cv. Sonia 17 & CHT: $2.5,5,7.5,10 \mathrm{mg} \cdot \mathrm{L}^{-1}$ & $\begin{array}{l}\text { The addition of } 7.5 \mathrm{mg} \mathrm{L}^{-1} \mathrm{CHT} \text { resulted in the } \\
\text { highest number of spikes/plant }(9.93) \text {, number } \\
\text { of florets/spike }(8.45) \text {, spike length }(32.87 \mathrm{~cm}) \text {, } \\
\text { and flower diameter }(7.92 \mathrm{~cm}) .\end{array}$ & {$[57]$} \\
\hline $\begin{array}{l}\text { Green } \\
\text { house }\end{array}$ & Dendrobium Suree Peach & CHT: $0,10,30,50,100 \mathrm{mg} \mathrm{L}^{-1}$ & $\begin{array}{l}\text { At } 10 \text { weeks after transplanting in the } \\
\text { greenhouse, the application of } 100 \mathrm{mg} \cdot \mathrm{L}^{-1} \mathrm{CHT} \text {, } \\
\text { together with } 5 \mathrm{~g} \cdot \mathrm{L}^{-1} \text { lotus extract, resulted in the } \\
\text { highest number of leaves }(8.5) .\end{array}$ & {$[58]$} \\
\hline $\mathrm{KC}$ & Vanda helvola & $\begin{array}{l}\text { TJ: } 0,10,15,20,40 \%(\mathrm{v} / \mathrm{v}) \\
\text { CW: } 0,10,15,20 \%(\mathrm{v} / \mathrm{v}) \\
\text { P: } 0,0.1,0.2,0.3 \%(\mathrm{w} / \mathrm{v})\end{array}$ & $\begin{array}{l}\text { After } 90 \text { days of cultivation, KC medium } \\
\text { supplemented with } 15 \% \mathrm{TJ} \text { was the most suitable } \\
\text { for seed germination, and } 40 \% \mathrm{TJ} \text { supported the } \\
\text { highest root number and length, as well as the } \\
\text { widest leaf width. David et al. [59] also reported } \\
\text { that the KC medium supplemented with TJ } \\
\text { promoted rapid germination of seed ( } 23 \text { days) } \\
\text { when compared to the control without TJ ( } 28 \\
\text { days). Plantlets regenerated via the in vitro seed } \\
\text { germination process were successfully } \\
\text { acclimatized in greenhouse conditions. }\end{array}$ & {$[59]$} \\
\hline $\begin{array}{l}1 / 2 \mathrm{MS} \\
\mathrm{MS} \\
\mathrm{KC} \\
\end{array}$ & Geodorum densiflorum & $\begin{array}{l}\text { TJ: } 5,10,15 \%(\mathrm{v} / \mathrm{v}) \\
\text { CW: } 5,10,15 \%(\mathrm{v} / \mathrm{v}) \\
\text { PH: } 5,10,15 \%(\mathrm{v} / \mathrm{v})\end{array}$ & $\begin{array}{l}\text { The } 1 / 2 \text { MS medium supplemented with } 5 \% \mathrm{TJ} \\
\text { resulted in the highest germination rate and } \\
\text { protocorm growth. }\end{array}$ & {$[60]$} \\
\hline VW & Vanda Kasem's Delight & $\begin{array}{l}\text { PH: } 0,5,10,20,30 \%(\mathrm{w} / \mathrm{v}) \\
\text { PE: } 0,5,10,20,30 \%(\mathrm{w} / \mathrm{v}) \\
\text { TJ: } 0,5,10,20,30 \%(\mathrm{v} / \mathrm{v})\end{array}$ & $\begin{array}{l}\text { VW medium supplemented with } 20 \text { and } 30 \% \text { TJ } \\
\text { promoted rapid PLB development. }\end{array}$ & {$[61]$} \\
\hline MS & Dimorphorchis rossii & YE: $0,0.1,0.2,0.3 \%(\mathrm{w} / \mathrm{v})$ & $\begin{array}{c}\text { Protocorm proliferation was highest on } 0.2 \% \text { YE } \\
\text { (41.67\%), followed by the control }(33.33 \%), 0.3 \% \\
\text { YE }(31.25 \%) \text {, and } 0.1 \% \text { YE }(12.50 \%) \text { after } 130 \\
\text { days of culture. }\end{array}$ & {$[62]$} \\
\hline $\mathrm{KC}$ & Vanda dearei & $\begin{array}{c}\text { YE: } 0,0.15,0.2,0.25,0.5 \%(\mathrm{w} / \mathrm{v}) \\
\text { P: } 0,0.15,0.2,0.25,0.5 \%(\mathrm{w} / \mathrm{v}) \\
\text { BH: } 0,2.5,7.5,12.5 \%(\mathrm{w} / \mathrm{v}) \\
\text { CW: } 0,10,15,20 \%(\mathrm{v} / \mathrm{v}) \\
\text { TJ: } 0,10,15,20 \%(\mathrm{v} / \mathrm{v})\end{array}$ & $\begin{array}{l}\text { The addition of } 0.5 \% \text { YE significantly enhanced } \\
\text { seed germination ( } 85.9 \%) \text { and shortened } \\
\text { germination time to } 23 \text { days. Seedlings, } \\
\text { approximately } 6.5 \mathrm{~cm} \text { in height, were adapted to } \\
\text { the greenhouse environment and continued to } \\
\text { develop into healthy plantlets. }\end{array}$ & {$[63]$} \\
\hline
\end{tabular}

\section{Peptone}

$\mathrm{P}$ is occasionally used as a medium supplement in orchid cultivation, facilitating explant growth and development. Numerous studies have shown that P supplements enhance germination (Table 1). For example, Utami et al. [33] evaluated the effect of different $P$ concentrations $(0,1,2$, and $\left.3 \mathrm{~g} \cdot \mathrm{L}^{-1}\right)$ on seed germination and shoot formation of Dendrobium lasianthera, observed at 4, 8, and 12 weeks after culture. Among the different concentrations of $\mathrm{P}$ tested, seed germination rate $(100 \%)$ was obtained after 12 weeks of incubation in all treatments. However, they also reported that shoot formation was the highest $(84.0 \%)$ in the Vacin and Went medium (VW; Vacin and Went [75]) supplemented with $2 \mathrm{~g} \cdot \mathrm{L}^{-1} \mathrm{P}$. Seed germination rates of Epidendrum ibaguense Kunth and ornamental orchid Spathoglottis plicata Blume were higher on M or Phytamax medium (PM; Phytamax $^{\mathrm{TM}}$, Sigma Chemical Co., USA) supplemented with $2 \mathrm{~g} \cdot \mathrm{L}^{-1} \mathrm{P}$ than on treatments that did not contain P $[34,35]$. Similarly, Buyun et al. [36] found a seed germination rate of $100 \%$ for Dendrobium parishii with Knudson medium (KC; Knudson [13]) supplemented with $2 \mathrm{~g} \cdot \mathrm{L}^{-1} \mathrm{P}$. According to Srivastava et al. [37], the seed germination rate of Aerides ringens increased significantly when cultured on $\mathrm{KC}$ 


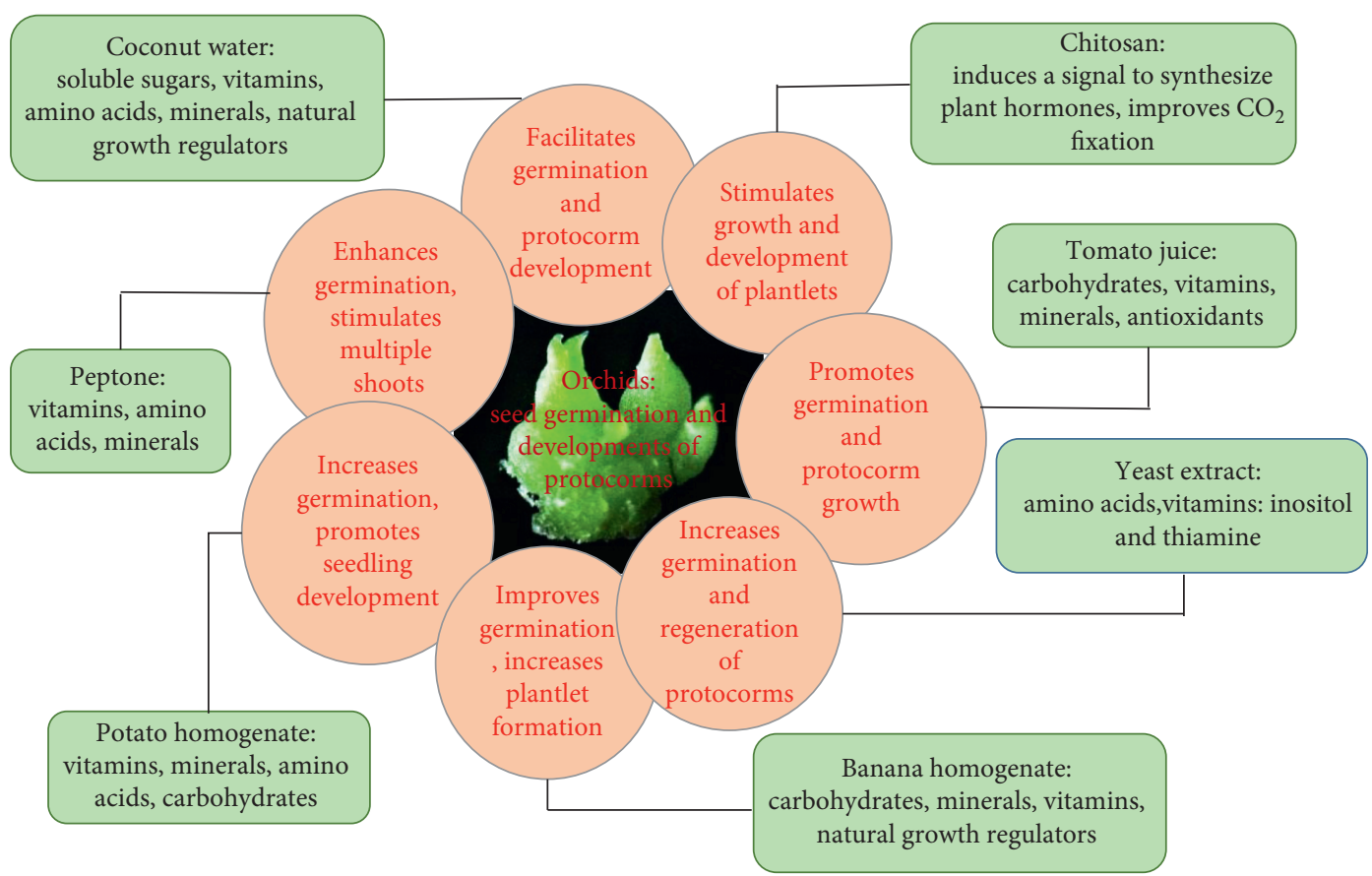

FIGURE 1: Overview on the contents and roles of some organic supplements in seed germination and further development of the protocorm in orchids.

medium containing $8.9 \mu \mathrm{M}$ benzylamino purine (BAP) and supplemented with $\mathrm{P}$. Among the different concentrations of $\mathrm{P}$ tested $\left(0.25,0.5\right.$, and $\left.0.75 \mathrm{~g} \cdot \mathrm{L}^{-1}\right)$, the highest germination rate $(89.28 \%)$ was obtained in $0.5 \mathrm{~g} \cdot \mathrm{L}^{-1} \mathrm{P}$ as an additive after 30 days of incubation.

$\mathrm{P}$ is also known to stimulate the multiple shoot and protocorms formation. Devi et al. [38] reported that $\mathrm{P}$ improved the in vitro multiplication of protocorms of medicinal epiphytic orchid Taprobanea spathulata. Of the different concentrations tested, $5 \mathrm{~g} \cdot \mathrm{L}^{-1} \mathrm{P}$ was a suitable concentration for the induction of multiple protocorms. Kaur and Bhutani [39] evaluated the effects of different organic additives $(\mathrm{BH}$ and $\mathrm{P})$ at various concentrations on the in vitro multiplication of shoots in Paphiopedilum venustum and discovered that modified terrestrial orchid medium (BM-1; Waes and Debergh [76]) supplemented with $\mathrm{P}\left(1 \mathrm{~g} \cdot \mathrm{L}^{-1}\right)$ was the most effective in stimulating multiple shoots, with three shoots per explant. In addition to promoting the formation of multiple shoots and protocorms, peptone promotes seedling growth [77] because it contains high levels of amino acids [78] and vitamins, including thiamin, biotin, pyridoxine, and nitrogen [79].

\section{Potato Homogenate}

Orchid seed germination was significantly affected by the presence of $\mathrm{PH}$ in the medium (Table 1). Islam et al. [40] evaluated the effect of $\mathrm{PH}$ on in vitro germination of Vanda roxburgii and showed that Hyponex medium supplemented with $\mathrm{PH}$ increased the seed germination rate and promoted seedling development. Similarly, Bakar et al. [41] evaluated the effect of different organic supplements $(\mathrm{PH}, \mathrm{CW}$, and $\mathrm{TJ})$ at various concentrations on seed germination of
Dimorphorchis lowii and found that $10 \%(\mathrm{w} / \mathrm{v})$ of $\mathrm{PH}$ resulted in the highest seed germination rates. Additionally, PH enhanced seedling growth of Dendrobium tosaense [42] and stimulated the multiplication and growth of Dendrobium officinale shoots [43]. Besides, $75 \mathrm{~g} \cdot \mathrm{L}^{-1} \mathrm{PH}$ in VW medium containing $100 \mathrm{~mL} \cdot \mathrm{L}^{-1} \mathrm{CW}$ was most suitable for in vitro proliferation in Bulbophyllum nipondhii pseudobulbs [44].

$\mathrm{PH}$ contains important vitamins, such as $\mathrm{C}, \mathrm{B} 1$, and B6, and mineral elements, such as potassium, iron, and magnesium, as well as carbohydrates and amino acids, which facilitate seed germination [80, 81]. Miransari and Smith [82] reported that seeds consume large amounts of nitrogen during germination, and therefore $\mathrm{PH}$ in the medium can influence germination rates.

\section{Banana Homogenate}

Seed germination and protocorm development were affected by $\mathrm{BH}$ in the media (Table 1). Pereira et al. [45] evaluated the effects of different organic additives (BH and $\mathrm{TJ}$ ) on the germination of Chloraea gavilu and showed that Malmgren modified terrestrial orchid medium (MM; Malmgren [83]) supplemented with $\mathrm{BH}$ successfully improved seed germination.

Islam et al. [46] investigated the effects of different $\mathrm{BH}$ concentrations $(0,2.5,5,10$, and $20 \%$; w/v) on the growth and development of PLBs Dendrobium sp. and showed that $1 / 2$ MS medium supplemented with $10 \% \mathrm{BH}$ was the most suitable for PLBs regeneration. According to Zeng et al. [47], plantlet formation of ornamental lithophytic orchid Paphiopedilum hangianum increased significantly when PLBs were subcultured on $\mathrm{HO}_{26}$ medium (Zeng et al. [84]) 
containing $1 \mathrm{~g} \cdot \mathrm{L}^{-1} \mathrm{P}$ and $1 \mathrm{mg} \cdot \mathrm{L}^{-1} \mathrm{NAA}$ and supplemented with $\mathrm{BH}$. The same study concluded that Harvais medium (Harvais [85]) with various organic supplements effectively induced seedling growth of Cypripedium macranthos. Among the various organic supplements studied (CW, $\mathrm{PH}$, and $\mathrm{BH}), \mathrm{BH}$ at a concentration of 25 or $50 \mathrm{~g} \cdot \mathrm{L}^{-1}$ improved shoot and root number and shoot and root length [48]. Gonçalves et al. [49] found that the number of Hadrolaelia purpurata seedlings produced was the highest on $\mathrm{KC}$ medium containing $90 \mathrm{~g} \cdot \mathrm{L}^{-1}$ of $\mathrm{BH}$. Furthermore, Utami and Hariyanto [50] observed the effect of supplementation with $150 \mathrm{~mL} \cdot \mathrm{L}^{-1} \mathrm{CW}$ with different $\mathrm{BH}$ concentrations $(0,5,10$, $\left.15 \mathrm{~g} \cdot \mathrm{L}^{-1}\right)$ on the plantlet development of Phalaenopsis amboinensis and found that the organic supplementation of $\mathrm{CW}$ together with $\mathrm{BH}$ had significantly increased the growth of plantlets. Banana has often been used as an organic additive in in vitro cultures because of its high levels of potassium, manganese, calcium, sodium, iron, zinc, thiamin, riboflavin, niacin, pyridoxine, pantothenic acid, ascorbic acid, folic acid [86], and natural growth regulators such as zeatin, gibberellin, and IAA $[87,88]$. It is also rich in carbohydrates, supplying energy to heterotrophic plants during the early stages of in vitro cultivation [89].

\section{Chitosan}

CHT, a biopolymer derivate of chitin, is mostly found in the exoskeleton of arthropods and crustaceans [90] and has been applied in various fields, including agriculture [91].

Numerous studies have shown that orchid seed germination is affected by the addition of CHT to the media (Table 1). Kananont et al. [51] studied the effects of various types of CHT at different concentrations on the seed germination of various orchid species and found that none of the six CHT types tested (CHT polymers: $\mathrm{P}_{70}, \mathrm{P}_{80}, \mathrm{P}_{90}$; CHT oligomers: $\left.\mathrm{O}_{70}, \mathrm{O}_{80}, \mathrm{O}_{90}\right)$ at five concentrations $(0,10$, 20, 40, and $80 \mathrm{mg} \cdot \mathrm{L}^{-1}$ ) had a significant effect on seed germination in Dendrobium bigibbum var. compactum; however, the addition significantly increased germination in Dendrobium formosum. The highest germination rate (91.2\%) was recorded using $\mathrm{CHT}$ type $\mathrm{O}_{80}$ at $10 \mathrm{mg} \cdot \mathrm{L}^{-1}$. Restanto et al. [52] evaluated the effect of CHT on zygotic embryo development of Dendrobium sp. in vitro and observed that CHT significantly affected zygotic embryo growth and differentiation. Of the different CHT concentrations tested $\left(0,5,10,15,20\right.$, and $\left.25 \mathrm{mg} \cdot \mathrm{L}^{-1}\right)$, the PLB number, PLB fresh weight, and number of plantlets were the highest using $15 \mathrm{mg} \cdot \mathrm{L}^{-1}$ of $\mathrm{CHT}$. Nge et al. [53] also studied the effect of shrimp CHT at different concentrations $\left(0,5,10,15,20\right.$, and $\left.25 \mathrm{mg} \cdot \mathrm{L}^{-1}\right)$ on the meristematic bud growth of Dendrobium phalaenopsis and showed that VW medium supplemented with $15 \mathrm{mg} \cdot \mathrm{L}^{-1} \mathrm{CHT}$ resulted in the highest fresh weight of PLBs. Additionally, the same study concluded that $1 / 2$ MS liquid medium supplemented with CHT effectively induced PLB development of Grammatophyllum speciosum. Of the different concentrations of CHT tested $\left(0,5,10,15,20,25,50\right.$, and $\left.100 \mathrm{mg} \cdot \mathrm{L}^{-1}\right)$, a concentration of $15 \mathrm{mg} \cdot \mathrm{L}^{-1}$ resulted in the highest growth rate (4-fold increase) [54]. Samarfard and Kadir [55] investigated the effects of CHT on PLB proliferation in Phalaenopsis gigantea, and among the six concentrations $\left(0,5,10,15,20\right.$, and $\left.25 \mathrm{mg} \cdot \mathrm{L}^{-1}\right)$ tested, $10 \mathrm{mg} \cdot \mathrm{L}^{-1} \mathrm{CHT}$ in VW medium resulted in the highest fresh weight after 20 weeks of cultivation.

Chitosan is also known to stimulate plantlet growth and development under greenhouse conditions. Pitoyo et al. [56] studied the effects of CHT on the growth of Grammatophyllum scriptum plantlets and suggested that CHT had significant effects on some parameters, including plantlet height and leaf length. Kumari et al. [57] investigated the effects of different CHT concentrations $(2.5,5$, 7.5 , and $10 \mathrm{mg} \cdot \mathrm{L}^{-1}$ ) on the growth and development of Dendrobium cv. Sonia 17. Of the four concentrations tested, $7.5 \mathrm{mg} \cdot \mathrm{L}^{-1}$ resulted in the highest number of spikes per plant, an increased flower diameter, an enhanced spike length, and a higher number of florets per spike. Similarly, Charoenwattana [58] studied the effects of CHT on the growth of plantlets of Dendrobium orchids and reported that an optimal leaf number was achieved at a concentration of $100 \mathrm{mg} \cdot \mathrm{L}^{-1}$ within 10 weeks of transplanting. The increase in plantlet growth was allegedly under the influence of photosynthesis. According to Barka et al. [92], the addition of CHT derivative, i.e., Chitogel, improved $\mathrm{CO}_{2}$ fixation by 1.5 -fold and $\mathrm{O}_{2}$ production by 2 -fold, indicating that CHT derivatives have the potential to increase photosynthesis, thereby increasing plant growth. According to Uthairatanakij et al. [93], the beneficial effect of CHT may induce a signal to synthesize plant hormones, auxin and gibberellin.

\section{Tomato Juice}

TJ significantly influences the germination of orchid seeds and subsequent protocorm development (Table 1). David et al. [59] investigated the effect of different complex additives (TJ, CW, P, and YE) at various concentrations on seed germination in Vanda helvola in vitro. In their study, KC medium supplemented with $15 \%$ (v/v) TJ was the most suitable for promoting germination. Muthukrishnan et al. [60] also examined the effects of various organic supplements (TJ, CW, and $\mathrm{PH}$ ) at different concentrations on seed germination in Geodorum densiflorum and showed that $1 / 2$ MS medium supplemented with $5 \%(\mathrm{v} / \mathrm{v})$ TJ resulted in the highest rate of seed germination and protocorm growth. Similarly, Gnasekaran et al. [61] reported that 20 and 30\% (v/v) TJ improved PLB proliferation in Vanda Kasem's Delight more than the addition of papaya extract (PE) or $\mathrm{PH}$.

Tomato juice contains carbohydrates, vitamins and minerals [94], glucose, and fructose [95], which benefit cellular division and support systems. Tomatoes also contain lycopene, a vigorous antioxidant with the ability to eliminate the formation of free radicals, repair injured cells, and suppress DNA oxidation [96]. Tomatoes also contain other antioxidants, such as $\alpha$-carotene, $\beta$-carotene, and ascorbic acid [97-100]. According to Gnasekaran et al. [61], sugars and antioxidants play an important role in cell proliferation and the production of healthy PLBs. 


\section{Yeast Extract}

YE is also an important source of amino acids and vitamins, especially inositol and thiamin, and has been effectively used to increase seed germination and regeneration in many orchid species [101]. Numerous studies have shown that orchid seed germination and protocorm regeneration are affected by YE in the cultivation media (Table 1). Gansau et al. [62] investigated the effect of different YE concentrations $(0,0.1,0.2$, and $0.3 \%$; w/v) on protocorm proliferation and growth of Dimorphorchis rossii. In their study, MS medium supplemented with $0.2 \%$ YE increased protocorm regeneration. Earlier, Jualang et al. [63] evaluated the effect of different organic supplements (YE, $\mathrm{P}, \mathrm{BH}, \mathrm{CW}$, and $\mathrm{TJ})$ at various concentrations on seed germination of Vanda dearei and found that $0.5 \%(\mathrm{w} / \mathrm{v})$ YE enhancement seed germination.

\section{Conclusion}

Based on the literature survey, we conclude that the addition of organic supplements, including $\mathrm{CW}, \mathrm{P}, \mathrm{BH}, \mathrm{PH}, \mathrm{CHT}$, TJ, and YE, to orchid seed germination media supports seed germination, precipitates seedling formation, and yields vigorous plantlets. They also effectively increase the number of PLBs, induce multiple shoot formation, and stimulate the growth and development of plantlets under greenhouse conditions. These organic supplements represent natural sources of amino acids, vitamins, minerals, organic acids, sugars, proteins, and natural growth regulators, assisting in orchid propagation by stimulating the development and morphogenesis in asymbiotic seed culture. Many orchid species are threatened by land conversion and habitat mismanagement. Asymbiotic seed germination with the addition of organic supplements is an excellent technique for the mass propagation and efficient acclimatization of orchids for reintroduction to natural habitats, which will facilitate the conservation of endangered orchid species.

\section{Data Availability}

The data used to support the findings of this study are included within the article.

\section{Conflicts of Interest}

The authors declare no conflicts of interest.

\section{Authors' Contributions}

Both authors contributed to literature search, participated in manuscript writing, and read and approved the final manuscript.

\section{Acknowledgments}

The authors gratefully acknowledge the financial support provided by the article review program of Universitas Airlangga, no. 955/UN3.14/LT/2019.

\section{References}

[1] M. J. M. Christenhusz and J. W. Byng, "The number of known plants species in the world and its annual increase," Phytotaxa, vol. 261, no. 3, pp. 201-217, 2016.

[2] B. Gravendeel, A. Smithson, F. J. W. Slik, and A. Schuiteman, "Epiphytism and pollinator specialization: drivers for orchid diversity," Philosophical Transactions of the Royal Society of London. Series B: Biological Sciences, vol. 359, no. 1450, pp. 1523-1535, 2004.

[3] P. Seaton, J. P. Kendon, H. W. Pritchard, D. M. Puspitaningtyas, and T. R. Marks, "Orchid concervation: the next ten years," Lankesteriana, vol. 13, no. 1-2, pp. 93-101, 2013.

[4] S. Zeng, W. Huang, K. Wu, J. Zhang, J. A. Teixeira da Silva, and J. Duan, "In vitro propagation of Paphiopedilum orchids," Critical Reviews in Biotechnology, vol. 36, no. 3, pp. 521-534, 2015.

[5] S. M. Vudala and L. L. F. Ribas, "Seed storage and asymbiotic germination of Hadrolaelia grandis (Orchidaceae)," South African Journal of Botany, vol. 108, pp. 1-7, 2017.

[6] S. Zhang, Y. Yang, J. Li et al., "Physiological diversity of orchids," Plant Diversity, vol. 40, no. 4, pp. 196-208, 2018.

[7] B. Long, A. X. Niemiera, Z.-Y. Cheng, and C.-L. Long, "In vitro propagation of four threatened Paphiopedilum species (Orchidaceae)," Plant Cell, Tissue and Organ Culture (PCTOC), vol. 101, no. 2, pp. 151-162, 2010.

[8] P. J. Kauth, W. A. Vendrame, and M. E. Kane, "In vitro seed culture and seedling development of Calopogon tuberosus," Plant Cell, Tissue and Organ Culture, vol. 85, no. 1, pp. 91102, 2006.

[9] A. Scade, M. C. Brundrett, A. L. Batty, K. W. Dixon, and K. Sivasithamparam, "Survival of transplanted terrestrial orchid seedlings in urban bushland habitats with high or low weed cover," Australian Journal of Botany, vol. 54, no. 4, pp. 383-389, 2006.

[10] S. L. Steward and M. E. Kane, "Asymbiotic seed germination and in vitro seedling development of Habenaria macroceratitis (Orchidaceae), a rare Florida terrestrial orchid," Plant Cell Tissue and Organ Culture, vol. 86, pp. 147-158, 2006.

[11] V. Nanekar, V. Shriram, V. Kumar, and P. B. K. Kishor, "Asymbiotic in vitro seed germination and seedling development of Eulophia nuda Lindl., an endangered medicinal orchid," Proceedings of the National Academy of Sciences, India Section B: Biological Sciences, vol. 84, no. 3, pp. 837-846, 2014.

[12] K. Sathiyadash, T. Muthukumar, S. B. Murugan et al., "In vitro asymbiotic seed germination, mycorrhization and seedling development of Acampae praemorsa (Roxb.) Blatt. \& Mc Cann, a common south Indian orchid," Asian Pacific Journal of Reproduction, vol. 2, no. 2, pp. 114-118, 2013.

[13] L. Knudson, "Nonsymbiotic germination of orchid seeds," Botanical Gazette, vol. 73, no. 1, pp. 1-25, 1922.

[14] J. Arditti and A. K. A. Ghani, “Tansley review no. 110," New Phytologist, vol. 145, no. 3, pp. 367-421, 2000.

[15] M. Molvray and P. J. Kores, "Character analysis of the seed coat in Spiranthoideae and Orchidoideae, with special reference to the diurideae (Orchidaceae)," American Journal of Botany, vol. 82, no. 11, pp. 1443-1454, 1995.

[16] J. Verma, K. Sharma, K. Thakur, J. K. Sembi, and S. P. Vij, "Study on seed morphometry of some threatened western Himalayan orchids," Turkish Journal of Botany, vol. 38, pp. 234-251, 2014.

[17] B. Chaudhary, P. Chattopadhyay, and N. Banerjee, "Modulations in seed micromorphology reveal signature of adaptive 
species-diversification in Dendrobium; (Orchidaceae)," Open Journal of Ecology, vol. 4, no. 2, pp. 33-42, 2014.

[18] J. Prutsch, A. Schardt, and R. Schill, "Adaptations of an orchid seed to water uptake and -storage," Plant Systematics and Evolution, vol. 220, no. 1-2, pp. 69-75, 2000.

[19] M. Fonnesbech, "Organic nutrients in the media for propagation of Cymbidium in vitro," Physiologia Plantarum, vol. 27 , no. 3, pp. 360-364, 1972.

[20] M. A. S. Prando, P. Chiavazza, A. Faggio, and C. Contessa, "Effect of coconut water and growth regulator supplements on in vitro propagation of Corylus avellana L," Scientia Horticulturae, vol. 171, pp. 91-94, 2014.

[21] S. A. S. Mercado and N. A. V. Contreras, "Asymbiotic seed germination and in vitro propagation of Cattleya trianae Linden \& Reichb.f. (Orchidaceae)," Acta Agronomica, vol. 66, no. 4, pp. 544-548, 2017.

[22] M. O. Islam, A. R. M. M. Rahman, S. Matsui, and A. K. M. A.-U.-D. Prodhan, "Effects of complex organic extracts on callus growth and PLB regeneration through embryogenesis in the Doritaenopsis orchid," Japan Agricultural Research Quarterly: JARQ, vol. 37, no. 4, pp. 229235, 2003.

[23] T. D. Thomas and A. Michael, "High-frequency plantlet regeneration and multiple shoot induction from cultured immature seeds of Rhynchostylis retusa Blume, an exquisite orchid," Plant Biotechnology Reports, vol. 1, no. 4, pp. 243249, 2007.

[24] H. Piri, P. Pathak, and R. K. Bhanwra, "Asymbiotic germination of immature embryos of a medicinally important epiphytic orchid Acampe papillosa (Lindl.) Lindl," African Journal of Biotechnology, vol. 12, no. 2, pp. 162-167, 2013.

[25] Y. S. Huh, J. K. Lee, S. Y. Nam, K. Y. Paek, and G. U. Suh, "Improvement of asymbiotic seed germination and seedling development of Cypripedium macranthos Sw. with organic additives," Journal of Plant Biotechnology, vol. 43, no. 1, pp. 138-145, 2016.

[26] S. Zeng, K. Wu, J. A. Teixeira da Silva et al., "Asymbiotic seed germination, seedling development and reintroduction of Paphiopedilum wardii Sumerh, an endangered terrestrial orchid," Scientia Horticulturae, vol. 138, pp. 198-209, 2012.

[27] K. Wu, S. Zeng, D. Lin et al., "In vitro propagation and reintroduction of the endangered Renanthera imschootiana Rolfe," PLoS One, vol. 9, no. 10, Article ID e110033, 2014.

[28] M. A. Baque, Y. K. Shin, T. Elshmari, E. J. Lee, and K. Y. Paek, "Effect of light quality, sucrose and coconut water concentration on the microprorpagation of Calanthe hybrids (Bukduseong x Hyesung and Chunkwang x Hyesung)," Australian Journal of Crop Science, vol. 5, no. 10, pp. 12471254, 2011.

[29] S. Maharjan, S. Pradhan, B. B. Thapa, and B. Pant, "In vitro propagation of endangered orchid, Vanda pumila Hook.f. through protocorms culture," American Journal of Plant Sciences, vol. 10, no. 7, pp. 1220-1232, 2019.

[30] T. Punjansing, M. Nakkuntod, S. Homchan, P. Inthima, and A. Kongbangkerd, "Influence of organic supplements on shoot multiplication efficiency of Phaius tankervilleae var.alba," International Journal of Agricultural and Biosystems Engineering, vol. 13, no. 4, pp. 105-109, 2019.

[31] J. E. Jainol and A. G. Jualang, "In vitro shoot multiplication and rooting of shoot tip explants of Dimorphorchis lowit: an endemic orchid of Borneo," Journal of Tropical Plant Physiology, vol. 7, pp. 14-25, 2015.

[32] S. Kaur, P. Bhandari, and K. K. Bhutani, "Characterization of bioactive compounds at seedling stage and optimization of seed germination, culture multiplication of Dendrobium nobile Lindl-a study in vitro," International Journal of Advanced Research, vol. 4, pp. 1041-1052, 2015.

[33] E. S. W. Utami, S. Hariyanto, and Y. S. W. Manuhara, "In vitro propagation of the endangered medicinal orchid, Dendrobium lasianthera J. J. Sm through mature seed culture," Asian Pacific Journal of Tropical Biomedicine, vol. 7, no. 5, pp. 406-410, 2017.

[34] M. M. Hossain, "Asymbiotic seed germination and in vitro seedling development of Epidendrum ibaguense Kunth. (Orchidaceae)," African Journal of Biotechnology, vol. 7, no. 20, pp. 3614-3619, 2008.

[35] M. M. Hossain and R. Dey, "Multiple regeneration pathways in Spathoglottis plicata Blume-a study in vitro," South African Journal of Botany, vol. 85, pp. 56-62, 2013.

[36] L. Buyun, A. Lavrentyeva, L. Kovalska, and R. Ivannikov, "In vitro germination of seeds of some rare tropical orchids," Acta Universitatis Latviensis Biology, vol. 676, no. 1, pp. 159-162, 2004.

[37] D. Srivastava, M. C. Gayatri, and S. K. Sarangi, "In vitro seed germination and plant regeneration of an epiphytic orchid Aerides ringens (Lindl.) Fischer," Indian Journal of Biotechnology, vol. 14, pp. 574-580, 2015.

[38] N. P. Devi, B. Lisipriya, and N. Bai, "Asymbiotic seed germination and mass multiplication of Tabrobanea spathulata (L.) Christenson (Asaparagales: Orchidaceae): a medicinally impoatant epiphytic orchid," Journal of Biological Sciences, vol. 2, no. 4, pp. 271-286, 2015.

[39] S. Kaur and K. K. Bhutani, "Asymbiotic seed germination and multiplication of an endangered orchid Paphiopedilum venustum (Wall. ex Sims.)," Acta Societatis Botanicorum Poloniae, vol. 85, no. 2, pp. 1-11, 2016.

[40] M. Islam, M. Akter, and A. Prodhan, "Effect of potato extract on in vitro seed germination and seedling growth of local Vanda roxburgii orchid," Journal of the Bangladesh Agricultural University, vol. 9, no. 2, pp. 211-215, 2011.

[41] B. Bakar, M. A. Latip, and J. A. Gansau, "Asymbiotic germination and seedling development of Dimorphics lowii (Orchidaceae)," Asian Journal of Plant Biology, vol. 2, no. 1, pp. 28-33, 2014.

[42] S. F. Lo, S. M. Nalawade, C. L. Kuo, C. L. Chen, and H. S. Tsay, "Asymbiotic germination of immature seeds, plantlet development and ex vitro establishment of plants of Dendrobium tosaense Makino-A medicinally important orchid," In Vitro Cellular and Developmental Biology-Plant, vol. 40, no. 5, pp. 528-535, 2004.

[43] B. Chen, S. J. Trueman, J. Li, Q. Li, H. Fan, and J. Zhang, "Micropropagation of the endangered medicinal orchid Dendrobium officinale," Life Science Journal, vol. 11, no. 9, pp. 526-530, 2014.

[44] W. Pakum, S. Watthana, K. O. Srimuang, and A. Kongbangkerd, "Influence of medium component on in vitro propagation of Thai's endangered orchid: Bulbophyllum nipondii Seidenf," Plant Tissue Culture and Biotechnology, vol. 26, no. 1, pp. 37-46, 2016.

[45] G. Pereira, V. Albornoz, C. Romero et al., "Asymbiotic germination in three Chloraea species. (Orchidaceae) from Chile," Gayana Botanica, vol. 74, no. 1, pp. 131-139, 2017.

[46] M. O. Islam, M. S. Islam, and M. A. Saleh, "Effect of banana extract on growth and development of protocorm like bodies in Dendrobium species. orchid," The Agriculturists, vol. 13, no. 1, pp. 101-108, 2015.

[47] S. Zeng, J. Wang, K. Wu, J. A. Teixeira da Silva, J. Zhang, and J. Duan, "In vitro propagation of Paphiopedilum hangianum 
perner \& gruss," Scientia Horticulturae, vol. 151, pp. 147-156, 2013.

[48] Y. Zhang, Y. I. Lee, L. Deng, and S. Zhao, "Asymbiotic germination of immature seeds and seedling development of Cypripedium macranthos Sw., an endangered Lady's slipper orchid," Scientia Horticulturae, vol. 164, pp. 130-136, 2013.

[49] L. M. Gonçalves, E. C. Prizão, M. A. M. Gutierre, C. A. Mangolin, and M. F. P. S. Machado, "Use of complex supplements and light-differential effects for micropropagation of Hadrolaelia purpurata (=Laelia purpurata) and Encyclia randii orchids," Acta Scientiarum Agronomy, vol. 34, no. 4, pp. 459-463, 2012.

[50] E. S. W. Utami and S. Hariyanto, "In vitro seed germination and seedling development of a rare Indonesian native orchid Phalaenopsis amboinensis," Scientifica, vol. 2019, Article ID 8105138, 6 pages, 2019.

[51] N. Kananont, R. Pichyangkura, S. Chanprame, S. Chadchawan, and P. Limpanavech, "Chitosan specificity for the in vitro seed germination of two Dendrobium orchids (Asparagales: Orchidaceae)," Scientia Horticulturae, vol. 124, no. 2, pp. 239-247, 2010.

[52] D. P. Restanto, B. Santoso, B. Kriswanto, and S. Supardjono, "The application of chitosan for protocorm like bodies (PLB) induction of orchid (Dendrobium species) in vitro," Agriculture and Agricultural Science Procedia, vol. 9, pp. 462-468, 2016.

[53] K. L. Nge, N. Nwe, S. Chandrkrachang, and W. F. Stevens, "Chitosan as a growth stimulator in orchid tissue culture," Plant Science, vol. 170, pp. 1185-1190, 2006.

[54] K. Sopalun, K. Thammasiri, and K. Ishikawa, "Effects of chitosan as the growth stimulator for Grammatophyllum speciosum in vitro culture," World Academy of Science, Engineering and Technology International Journal of Biotechnology and Bioengineering, vol. 4, no. 11, pp. 828-830, 2010.

[55] S. Samarfard and M. A. Kadir, "In vitro propagation and detection of somaclonal variation in Phalaenopsis gigantea as affected by chitosan and thidiazuron combinations," Horticultural Science, vol. 49, no. 1, pp. 82-88, 2014.

[56] A. Pitoyo, M. R. Hani, and E. Anggarwulan, "Application of chitosan spraying on acclimatization success of tiger orchid (Grammatophyllum scriptum) plantlets," Nusantara Bioscience, vol. 7, no. 2, pp. 185-191, 2015.

[57] S. Kumari, J. Singh, and F. G. Panj, "Economic returns and enhanced quality in orchid (Dendrobium sonia 17) using biosafe compound-chitosan," Agricultural Research and Technology, vol. 6, no. 3, pp. 1-5, 2017.

[58] P. Charoenwattana, "Effects of chitosan and Lotus extracts as growth promoter in Dendrobium orchid," International Journal of Environmental and Rural Development, vol. 4, no. 2, pp. 133-137, 2013.

[59] D. David, R. Jawan, H. Marbawi, and J. A. Gansau, "Organic additives improves the in vitro growth of native orchid Vanda helvola Blume," Notulae Scientia Biologicae, vol. 7, no. 2, pp. 192-197, 2015.

[60] S. Muthukrishnan, T. S. Kumar, and M. V. Rao, "Effects of different media and organic additives on seed germination of Geodorum densiflorum (Lam) Schltr.-an endangered orchid," International Journal of Scientific Research, vol. 2, no. 8, pp. 23-26, 2013.

[61] P. Gnasekaran, R. Poobathy, M. Mahmood, M. R. Samian, and S. Subramaniam, "Effects of complex organic additives on improving the growth of PLBs of Vanda Kasem's delight," Australian Journal of Crop Science, vol. 6, no. 8, pp. 12451248, 2012.
[62] J. A. Gansau, R. Jawan, and S. J. Spiridrin, "Effect of yeast extract and coconut water on protocorm proliferation and growth development of Dimorphorchis rossii," Acta Biologica Malaysiana, vol. 4, no. 2, pp. 59-63, 2015.

[63] A. G. Jualang, D. Devina, M. Hartinie, J. S. Sharon, and J. Roslina, "Asymbiotic seed germination and seedling development of Vanda dearei," Malaysian Applied Biology, vol. 43, no. 2, pp. 25-33, 2014.

[64] J. Van Overbeek, M. E. Conklin, and A. F. Blakeslee, "Factors in coconut milk essential for growth and development of very young Datura embryos," Science, vol. 94, no. 2441, pp. 350-351, 1941.

[65] J. Van Overbeek, M. E. Conklin, and A. F. Blakeslee, "Cultivation in vitro of small Datura embryos," American Journal of Botany, vol. 29, no. 6, pp. 472-477, 1942.

[66] J. W. Yong, L. Ge, Y. F. Ng, and S. N. Tan, "The chemical composition and biological properties of coconut (Cocos nucifera L.) water," Molecules, vol. 14, no. 12, pp. 5144-5164, 2009.

[67] P. Gnasekaran, R. Xavier, R. S. Uma, and S. Sreeramanan, “A study on the use of organic additives on the protocorm-like bodies (PLBs) growth of Phalaenopsis violacea orchid," Journal of Phytology, vol. 2, pp. 29-33, 2010.

[68] U. Santoso, K. Kubo, T. Ota, T. Tadokoro, and A. Maekawa, "Nutrient composition of kopyor coconuts (Cocos nucifera L.)," Food Chemistry, vol. 57, no. 2, pp. 299-304, 1996.

[69] J. Arditti, Micropropagation of Orchids, Vol. 2, Blackwell Publishing, Hoboken, NJ, USA, 2nd edition, 2008.

[70] S. Kaur and K. K. Bhutani, "Organic growth supplement stimulants for in vitro multiplication of Cymbidium pendulum (Roxb.) Sw," Horticultural Science, vol. 39, no. 1, pp. 47-52, 2012.

[71] S. Tan, J. Yong, and L. Ge, "Analyses of phytohormones in coconut (Cocos nucifera L.) water using capillary electrophoresis-tandem mass spectrometry," Chromatography, vol. 1, no. 4, pp. 211-226, 2014.

[72] T. Murashige and F. Skoog, "A revised medium for rapid growth and bio-assays with tobacco tissue cultures," Physiologia Plantarum, vol. 15, no. 3, pp. 473-497, 1962.

[73] G. C. Mitra, R. N. Prasad, and A. Roychowdhary, "Inorganic salts and differentiation of protocorm in seed-callus of an orchid and correlated changes in its free amino acid content," Indian Journal Experimental Biology, vol. 14, pp. 350-351, 1976.

[74] K. Kano, "Studies on the media for orchid seed germination," Memories ot the Faculty of Agriculture Kagawa University, vol. 20, pp. 1-68, 1965.

[75] E. F. Vacin and F. W. Went, "Some pH changes in nutrient solutions," Botanical Gazette, vol. 110, no. 4, pp. 605-613, 1949.

[76] J. M. Waes and P. C. Debergh, "In vitro germination of some western European orchids," Physiologia Plantarum, vol. 67, no. 2, pp. 253-261, 1986.

[77] E. F. George, M. A. Hall, and G. J. de Klerk, Plant Propagation by Tissue Culture, Springer, Berlin, Germany, 3rd edition, 2007.

[78] D. T. Nhut, N. N. Thi, B. L. T. Khiet, and V. Q. Luan, "Peptone stimulates in vitro shoot and root regeneration of Avocado (Persea americana Mill.)," Scientia Horticulturae, vol. 115, no. 2, pp. 124-128, 2008.

[79] D. Dutra, M. E. Kane, L. Richardson, S. L. Stewart, M. E. Kane, and L. Richardson, "Asymbiotic seed germination, in vitro seedling development, and greenhouse acclimatization of the threatened terrestrial orchid Bletia 
purpurea," Plant Cell, Tissue and Organ Culture (PCTOC), vol. 96, no. 3, pp. 235-243, 2008.

[80] V. Bártová and J. Bárta, "Chemical composition and nutritional value of protein concentrates isolated from potato (Solanum tuberosum L.) fruit juice by precipitation with ethanol or ferric chloride," Journal of Agricultural and Food Chemistry, vol. 57, no. 19, pp. 9028-9034, 2009.

[81] Z. Molnár, E. Virag, and V. Ordog, "Natural substances in tissue culture media of higher plants," Acta Biologica Szegediensis, vol. 55, no. 1, pp. 123-127, 2011.

[82] M. Miransari and D. L. Smith, "Plant hormones and seed germination," Environmental and Experimental Botany, vol. 99, pp. 110-121, 2014

[83] S. Malmgren, "Large-scale asymbiotic propagation of Cypripedium calceolus - plant physiology from a surgeon's point of view," Botanic Gardens Micropropagation News, vol. 1, pp. 59-63, 1992.

[84] S. J. Zeng, Z. L. Chen, K. L. Wu et al., “Asymbiotic seed germination, induction of calli and protocorm-like bodies, and in vitro seedling development of the rare and endangered Nothodoritis zhejiangensis Chinese orchid," Horticultural Science, vol. 46, no. 3, pp. 460-465, 2011.

[85] G. Harvais, "An improved culture medium for growing the orchid Cypripedium reginae axenically," Canadian Journal of Botany, vol. 60, pp. 2547-2555, 1982.

[86] D. Mohapatra, S. Mishra, and N. Sutar, "Banana and its byproduct utilisation: an overview," Journal of Scientific and Industrial Research, vol. 69, no. 5, pp. 323-329, 2010.

[87] R. A. Khalifah, "Indolyl-3-acetic acid from the developing banana," Nature, vol. 212, no. 5069, pp. 1471-1472, 1996.

[88] R. A. Khalifah, "Gibberellin-like substances from the developing banana," Plant Physiology, vol. 41, no. 5, pp. 771-773, 1966.

[89] A. A. Al-Khateeb, "Regulation of in vitro bud formation of date palm (Phoenix dactylifera L.) cv. Khanezi by different carbon sources," Bioresource Technology, vol. 99, no. 14, pp. 6550-6555, 2008.

[90] C. Palpandi, V. Shanmugam, and A. Shanmugam, "Extraction of chitin and chitosan from shell and operculum of mangrove gastropod Nerita (Dostia) Crepidularia Lamarck," International Journal of Medicine and Medical Sciences, vol. 1, no. 5, pp. 198-205, 2009.

[91] K. Ohta, A. Tanguchi, N. Konishi, and T. Hosoki, "Chitosan treatment affect plant growth and flower quality in Eustoma grandiflorum," Horticultural Science, vol. 34, no. 2, pp. 233-234, 1999.

[92] E. A. Barka, P. Eullaffroy, C. Clèment, and G. Vernet, "Chitosan improves development, and protect Vitis vinifera L. against Botrytis cenerea," Plant Cell Reproduction, vol. 22, no. 8, pp. 608-614, 2004.

[93] A. Uthairatanakij, J. A. Teixeira Da Silva, and K. Obsuwan, "Chitosan for improving orchid production and quality," Orchid Science and Biotechnology, vol. 1, no. 1, pp. 1-5, 2007.

[94] A. Abdel-Rahman, "Nutritional value of some canned tomato juice and concentrates," Food Chemistry, vol. 9, no. 4, pp. 303-306, 1982.

[95] K. Markovic, M. Hruskar, and N. Vahcic, "Lycopene content of tomato products and their contribution to the lycopene intake of Croatians," Nutrition Research, vol. 26, no. 11, pp. 556-560, 2006.

[96] B. Halliwell, "Antioxidants," in Present Knowledge in Nutrition, E. E. Zeigler and L. J. Filer Jr., Eds., ILSI Press, Washington, DC, USA, 1996.
[97] A. M. Adalid, S. Rosello, and F. Nuez, "Evaluation and selection of tomato accessions (Solanum section Lycopersicon) for content of lycopene, $\beta$-carotene and ascorbic acid," Journal of Food Composition and Analysis, vol. 23, no. 6, pp. 613-618, 2010.

[98] V. García-Valverde, I. Navarro-González, J. García-Alonso, and M. J. María Jesús Periago, "Antioxidant bioactive compounds in selected industrial processing and fresh consumption tomato cultivars," Food Bioprocess Technology, vol. 6, no. 2, pp. 391-402, 2011.

[99] N. Manzo, F. Pizzolongo, G. Meca, A. Aiello, N. Marchetti, and R. Romano, "Comparative chemical compositions of fresh and stored vesuvian PDO "Pomodorino Del Piennolo" tomato and the Ciliegino variety," Molecules, vol. 23, no. 11, pp. 1-13, 2018.

[100] J. Mladenovic, G. Acamovic-Dokovic, R. Pavlovic, M. Zdravkovic, Z. Girek, and J. Zdravkovic, "The biologically active (bioactive) compounds in tomato (Lycopersicon esculentum Mill.) as a function of genotype," Bulgarian Journal of Agricultural Science, vol. 20, no. 4, pp. 877-882, 2014.

[101] G. C. Mitra, "In vitro culture of orchid seed: obtaining seedlings," in Biology, Conservation, and Culture of Orchids, S. P. Vij, Ed., pp. 401-412, Affiliated East-West Press, New Delhi, India, 1986. 